\title{
Identify the Severity of Cirrhosis Based on the Level of AST and ALT Enzymes Using Image Processing Approach and K-Means Clustering Method
}

\author{
Nunik Destria Arianti ${ }^{1}$, Azah Kamilah Muda ${ }^{2}$, Norashikin Ahmad ${ }^{3}$, Neny Rosmawarni ${ }^{4}$, \\ muhamad muslih ${ }^{5}$ \\ \{nunik@nusaputra.ac.id ${ }^{1}$, azah@utem.edu.my ${ }^{2}$, norashikin@utem.edu.my ${ }^{3}$, neny@istn.ac.id ${ }^{4}$, \\ muslih@nusaputa.ac.id $\left.{ }^{5}\right\}$ \\ Universiti Teknikal Malaysia Melaka, 75450 Melaka, Malaysia ${ }^{1}$ \\ Department of Information System, Nusa Putra University, Sukabumi, Indonesia ${ }^{2}$ \\ Department of Information Technology, National Institute of Science and Technology 3
}

\begin{abstract}
The liver is an organ in the body that has an important and complex task for the continuity of all bodily functions. In daily life, the human body deals with ingredients that have the potential to damage the liver, such as chemicals contained in the blood; as a result, the liver is susceptible to injury. In general, there are several diseases caused by viruses that can attack the liver, including Hepatitis, Hemochromatosis, Cirrhosis, Liver Cancer, Liver Abscess, and Impotence in the liver, but naturally, the liver can protect itself by regeneration. This paper presents a severity detection scheme for cirrhosis of the liver based on the Alanine Aminotransferase (ALT) and Aspartate Aminotransferase (AST) enzymes contained in the blood. Cirrhosis of the liver is a chronic liver disease characterized by damage to liver cells by connective tissues, followed by scarring and often accompanied by the formation of hundreds of nodules (lumps). This disease changes the structure of the liver from healthy liver tissue to abnormal hard bumps and changes in blood vessels. This system will assist medical experts and provide information to patients with liver cirrhosis to carry out further treatment based on predicting the state of a patient's liver presented in 3D images. The limitations of this study only present a prediction of the state of a person's liver, which is indicated to suffer from cirrhosis of the liver based on the content of ALT and AST enzymes in the blood. The impact of this study is that it can assist in decision making and analysis to refer to more specific parts that deal with cases of liver cirrhosis.
\end{abstract}

Keywords: Alanine Aminotransferase, Aspartate Aminotransferase, cirrhosis, image processing, K-Means clustering, liver.

\section{Introduction}

The liver is the only organ in the body that can easily replace damaged cells, but if the cells needed are lost, the liver cannot possibly meet the body's needs [1]. The liver is the second largest organ in the human body with a size about the size of a rugby ball and has two parts (lobes) right and left. The liver is located in the right upper abdomen just below the rib cage [2]. The liver has several functions including fat metabolism, protein metabolism, carbohydrate metabolism, hemoglobin metabolism, metabolism of drugs and poisons, aiding blood clots. The liver is an organ that can regenerate quickly to replace damaged cells. However, if the cells are 
damaged enough, the work of the liver in the body can be disrupted. Usually, liver function decreases when liver cell damage reaches $75 \%$ [3]. Liver disease can be caused by the workload of the body that is too large as the workers working in the agricultural sector $[4,5]$ and factory workers $[6,7]$.

Liver disease is the term used when the liver is disturbed, so it does not work properly [8]. Types of liver disease include hepatitis, cirrhosis, and liver cancer. The stages of liver tissue damage include the initial phase of the disease or inflammation (stage 1), liver fibrosis (stage 2), cirrhosis (stage 3), liver failure (stage 4).

Early diagnosis of liver disease is essential in fast and effective treatment. Liver function test is one of the tests conducted to measure the health of the liver [9]. Liver function tests are carried out by measuring the levels of specific chemical compounds in the blood, then comparing them to the standard values of these chemical compounds. If the results of chemical measurements show abnormal levels, a disease or liver damage can be suspected [10]. Some of the tests performed are Alanine Aminotransferase (ALT) and Aspartate Aminotransferase (AST) tests, albumin tests, bilirubin tests, ALP tests, GGT tests; this test is done by taking blood samples from veins. Therefore, this paper identifies the severity of cirrhosis based on the level of AST and ALT enzymes using the image processing approach and the K-Means clustering method.

\section{Literature Review}

The initial stages carried out in the process of data clustering using the K-Means algorithm is the formation of the cj centroid starting point. In general, the formation of centroid starting points is randomly generated. The number of centroid cj that is raised is in accordance with the number of clusters specified at the beginning. After the $\mathrm{k}$ centroid is formed then the distance of each data xi is calculated and the centroid is $\mathrm{j}$ to $\mathrm{k}$, denoted by $\mathrm{d}$ (xi, cj). There are several measures of distance used as a measure of the similarity of a data instance, one of which is the distance of Euclid [11]. Euclidean distance calculation as in Equation 1.

$$
d(X i, C j)=\sqrt{\sum_{i=1}^{N}(X i-C j)^{2}}
$$

Duran and Odell [12] state that if $\mathrm{d}(\mathrm{Xi}, \mathrm{Cj})$ gets smaller, the similarity between the two observation units is getting closer. The requirement to use Euclid distance is if all the features in the dataset are not correlated with each other. If there are correlated features then use the concept of distance Mahalanobis.

Agusta [13] states that the continuation of the distance is the closest so that the data will be grouped based on the closest centroid. The next step is to update the centroid point by calculating the average distance of all data towards the centroid. Then it will return to the initial process. This iteration will be repeated until it gets a constant centroid which means the centroid point has not changed anymore. Or iterations are stopped based on the maximum number of iterations specified.

\section{Methodology}

The type of research used in this study is the type of applied research. Applied research is a study to produce something that can be directly applied to solve a problem. In this paper, the 
author applies the K-Means algorithm using the Rstudio software open source. The research data was taken from the research objects of the Indian Liver Data (ILPD) data.

The K-Means algorithm is a clustering algorithm that groups data based on the center of the cluster (centroid) closest to the data. The purpose of K-Means is grouping data by maximizing the similarity of data in one cluster and minimizing the similarity of data between clusters. A measure of the similarity used in a cluster is a function of distance. So maximizing the similarity of data is obtained based on the shortest distance between the data to the centroid point.

\section{Result and Discussion}

Analysis to identify the severity of cirrhosis based on AST and ALT enzyme levels using the image processing approach and the k-means clustering method has been carried out. The number of clusters used is two consisting of liver which has detected pain and a healthy liver. The distribution of patients as a sample based on age is shown in Figure 1. Age of patients spread from 4 years to 90 years. The number of patients by gender on their age is shown in Figure 2.

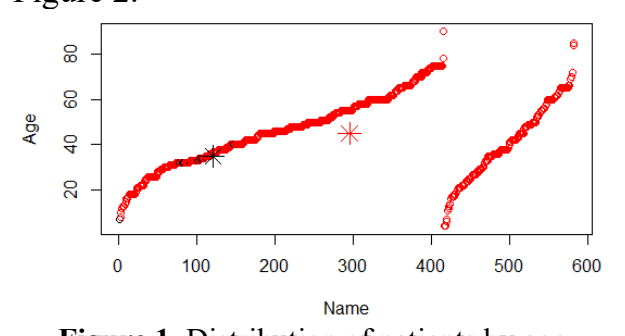

Figure 1. Distribution of patients by age

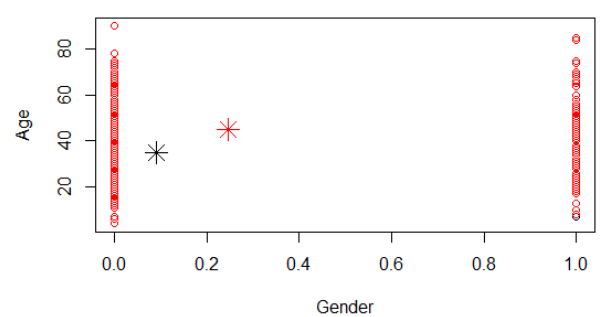

Figure 2. Gender distribution of patients with age

The distribution of ALT and AST content from the tested patients is presented in Figure 3 and Figure 4. The ALT and AST contents were distributed almost evenly in the patient sample.

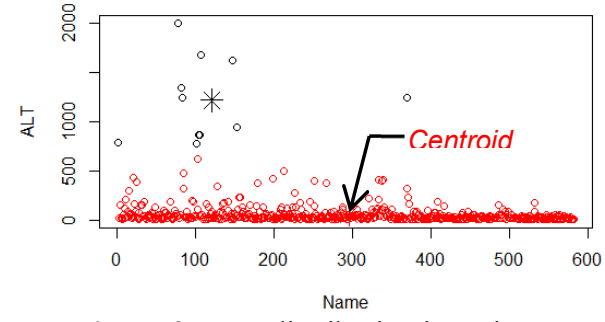

Figure 3. ALT distribution in patients

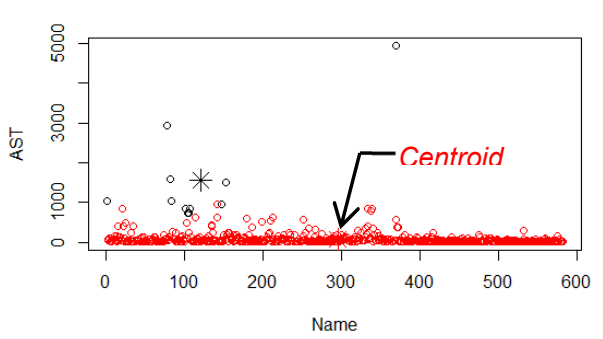

Figure 4. Distribution of AST in patients

\subsection{Relationship of patient's age to the content of ALT and AST in the liver}

The relationship between age and the content of ALT and AST in the starch body is presented in Figure 5 and Figure 6. The results show that the ALT content will increase with reduced performance from the liver. However, the AST content does not show anything significant about it. 


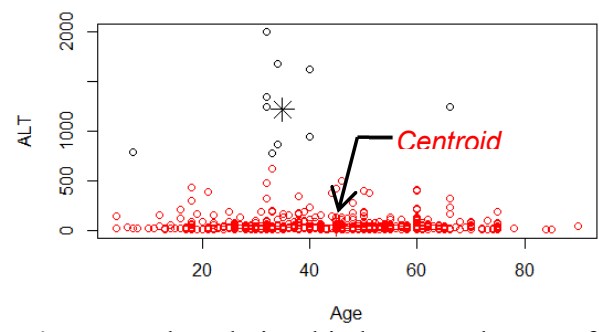

Figure 5. The relationship between the age of patients with ALT content in their liver

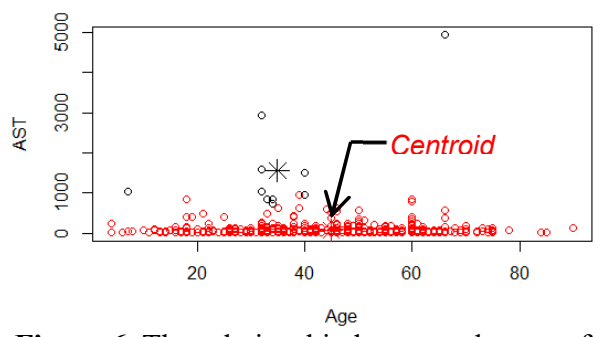

Figure 6. The relationship between the age of the patient and the AST content in his liver

\subsection{Gender relations with the content of ALT and AST in the liver}

The relationship between gender and the content of ALT and AST in the starch body is shown in Figure 7 and Figure 8. The results show that the content of ALT and AST is greater in men. This shows that men's liver is easier to find out through the content of ALT and AST than women.

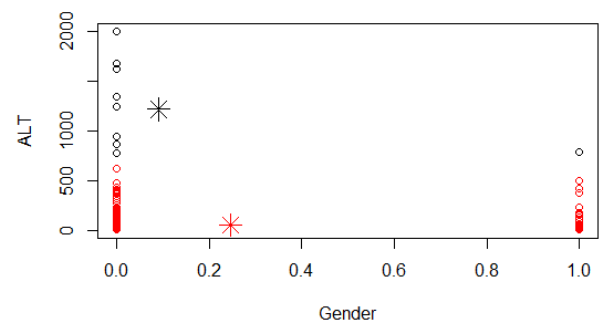

Figure 7. Relationship between gender of patients with ALT content in their liver

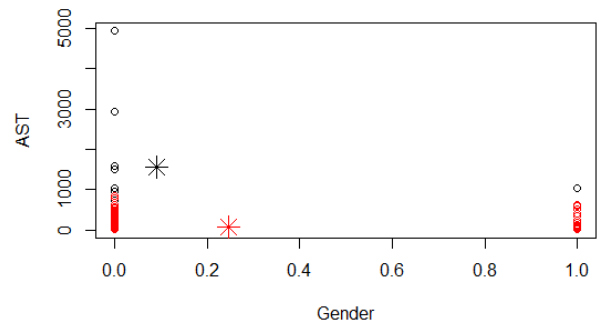

Figure 8. The relationship between the age of the patient and the AST content in his liver

\subsection{The condition of the liver to the content of ALT and AST}

The relationship between the condition of the liver and the content of ALT and AST in the starch body is shown in Figure 7 and Figure 8. The results show that the AST content is better in showing the patient's liver condition. The correlation between the content of ALT and AST against changes in liver condition through image processing analysis using the k-means clustering method was $32.6 \%$.

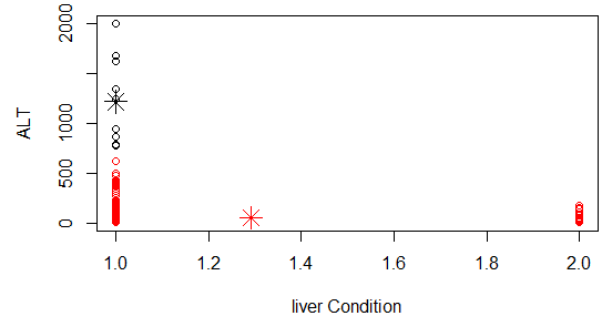

Figure 9. The condition of the liver against ALT content

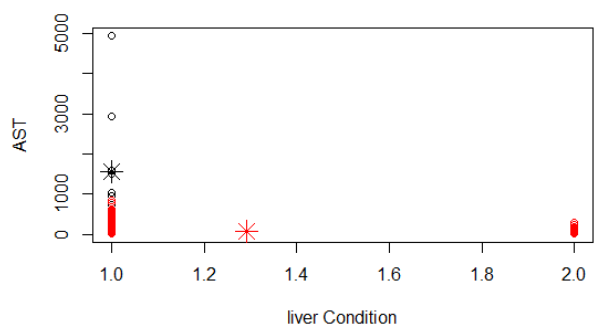

Figure 10. The condition of the liver against AST content 


\section{Conclusion}

Identify the severity of cirrhosis based on the level of ast and alt enzymes by using image processing approach and k-means clustering method has been taken from this research. The results of this study indicate that the content of ALT and AST enzymes can show early signs of liver damage. The appearance of images of a damaged liver shape has a relationship with the amount of ALT and AST enzymes. The future works from this research are increasing the number of liver samples observed and optimizing the results of image processing so that it can better show the actual state of the liver health condition.

\section{References}

[1] C. M. Chinnici, G. Pietrosi, G. Iannolo, G. Amico, N. Cuscino, V. Pagano, et al., "Mesenchymal stromal cells isolated from human fetal liver release soluble factors with a potential role in liver tissue repair," Differentiation, vol. 105, pp. 14-26, 2019/01/01/2019.

[2] R. B. Case, J.-J. Sonke, D. J. Moseley, J. Kim, K. K. Brock, and L. A. Dawson, "Interand intrafraction variability in liver position in non-breath-hold stereotactic body radiotherapy," International Journal of Radiation Oncology* Biology* Physics, vol. 75, pp. 302-308, 2009.

[3] H. Tilg and A. R. Moschen, "Evolution of inflammation in nonalcoholic fatty liver disease: the multiple parallel hits hypothesis," Hepatology, vol. 52, pp. 1836-1846, 2010

[4] R. Bulan, M. Yasar, Y. Nata, and A. Sitorus, "Design And Construction Of Chopper Machine Ae02-Type For Oil Palm Frond," INMATEH-Agricultural Engineering, vol. 57, 2019.

[5] A. Siwiendrayanti, "Keterlibatan dalam aktivitas pertanian dan keluhan Kesehatan Wanita Usia Subur," Jurnal Kesehatan Masyarakat, vol. 7, pp. 73-82, 2011.

[6] A. Sitorus, "Measurement of pyrolysis gases on palm oil shell and empty fruit bunch," in 2017 International Conference on Computing, Engineering, and Design (ICCED), 2017, pp. 1-4.

[7] A. Arianti, "Identifikasi Gejala Pada Pasien Dengan Life Limiting Illness," 2017.

[8] S. Bahashwan, M. H. Hassan, H. Aly, M. M. Ghobara, H. A. El-Beshbishy, and I. Busati, "Crocin mitigates carbon tetrachloride-induced liver toxicity in rats," Journal of Taibah university medical sciences, vol. 10, pp. 140-149, 2015.

[9] A. A. Dan, J. B. Kallman, R. Srivastava, Z. Younoszai, A. Kim, and Z. M. Younossi, "Impact of chronic liver disease and cirrhosis on health utilities using SF-6D and the health utility index," Liver Transplantation, vol. 14, pp. 321-326, 2008.

[10] C. D. Byrne, J. Patel, E. Scorletti, and G. Targher, "Tests for diagnosing and monitoring non-alcoholic fatty liver disease in adults," Bmj, vol. 362, p. k2734, 2018.

[11] A. Asroni and R. Adrian, "Penerapan metode K-means untuk clustering mahasiswa berdasarkan nilai akademik dengan Weka Interface studi kasus pada jurusan Teknik Informatika UMM Magelang," Semesta Teknika, vol. 18, pp. 76-82, 2016.

[12] P. L. Odell and B. S. Duran, Cluster Analysis: A Survey: Springer, 1974.

[13] Y. Agusta, "K-Means-Penerapan, Permasalahan dan Metode Terkait," Jurnal Sistem dan Informatika, vol. 3, pp. 47-60, 2007. 